\title{
Nadine Gordimer: De-Linking, Interrupting, Severing. Introduction
}

Fiona McCann and Kerry-Jane Wallart

\section{(2) OpenEdition \\ 1 Journals}

Electronic version

URL: https://journals.openedition.org/ces/416

DOI: $10.4000 /$ ces. 416

ISSN: 2534-6695

Publisher

SEPC (Société d'études des pays du Commonwealth)

\section{Printed version}

Date of publication: 10 June 2019

Number of pages: 5-9

ISSN: 2270-0633

\section{Electronic reference}

Fiona McCann and Kerry-Jane Wallart, "Nadine Gordimer: De-Linking, Interrupting, Severing. Introduction", Commonwealth Essays and Studies [Online], 41.2 | 2019, Online since 05 November 2019, connection on 18 July 2021. URL: http://journals.openedition.org/ces/416 ; DOI: https://doi.org/ $10.4000 /$ ces. 416

\section{(c) (i) $\odot$}

Commonwealth Essays and Studies is licensed under a Licence Creative Commons Attribution - Pas d'Utilisation Commerciale - Pas de Modification 4.0 International. 


\section{Nadine Gordimer: De-Linking, \\ Interrupting, Severing. \\ Introduction}

In a reflection about her own positionality, seen against the provisional and uncertain background of the "breaches and interstices that the ravelling-out of apartheid colonialism produced” (Writing 128), Nadine Gordimer recounts how her artistic calling preceded her political activism. In this essay, entitled "That Other World that Was the World," she explains that before she committed herself to the anti-apartheid struggle per se, she had mingled with black writers, painters, and actors, and that this formative period in her life showed her how her own "personal revolution [as a writer] had no other issue but to lead [her] into theirs" (130). Such a revolution is described as anything but a tabula rasa, or a black hole from which unformed matter can be shaped into a new society. Instead, in tones that are unusually hopeful under her pen, Gordimer writes of mending fragmentation:

Only in the prescient dimension of the imagination could I bring together what had been deliberately broken and fragmented; fit together the shapes of living experience, my own and that of others, without which a whole consciousness is not attainable. I had to be part of the transformation of my place in order for it to know me. (Writing 130)

In this passage, the compartmentalization, segregation and discrimination upon which the regime of apartheid was premised is countered by the sense of becoming part of a new order. In the wake of Graham Riach's analysis of her late style and its "structural fracture" (1077), which he sees as particularly blatant in the short story collection Jump, our contention is that the "breaches," interruptions, disruptions, disjunctions, cracks, breaks and fractures are still very much apparent in a number of works, early or late. This volume was born from an attempt at mapping out the forms taken by such ruptures.

They are obviously geographical, interrogating a space that has been divided to secure the lion's share for the white population, and to relegate non-whites to Bantustans and townships. They are also temporal. Alongside her developing a forceful "art of the present moment" (Gordimer, "Short Story" 15), Gordimer's writing is nonetheless haunted by the ghostly traumas of a colonial past and "always in some way in dialogue with an absent future" (Clingman 13). This resonates in new ways a few years after her death, as post-apartheid South Africa continues to undergo major social, economic, political and cultural changes. While all chronological (let alone teleological) timelines also appear fractured in Gordimer's oeuvre, some reconfigurations of linearity find their way in, making for patterns which radiate at all other levels: spatial, ideological, affective, narrative and metafictional. In other words, the irruption of violence exerted in diegeses can also be read as reiteration, but also possibly as a means towards a new order. Such literary moments of non-linearity and reconnection are crucial to how the South African author intends to intervene in the world she is showing; to how transformative and performative her writings may be in their re-casting fissured agencies. Calling attention to such processes as linkage and re-connection is also a way of considering anew the "interregnum" in and on which she dwelt (see Gordimer, Essential Gesture), a place where destruction rules but where odd collocations emerge where and when least 
expected. Likewise, odd reconfigurations can be witnessed at temporal but also narratological levels, suggesting possibilities for meaning to circulate again, at times of crises. The notion of crisis, with its etymological connection to the act of separation, reveals both the challenges, and the necessary failure, of interpretation of passages such as the moment when, in The Late Bourgeois World, the narrator's heart repeats "afraid, alive, afraid, alive, afraid, alive..." (43).

Beyond the specificities of the South African context, fragmentation is a useful concept when one wants to probe the relation between past and present, between events and historiography, between lost testimonies and belated archives. De Certeau writes, "The book on Loudun took shape in this in-between. It is cracked from top to bottom, revealing the combination, or relation, which makes History possible." ${ }^{\text {"T }}$ The crack pointed out by De Certeau constituted a moment of resistance to the epistemic violence inherent in Western modernity, and the resulting need for equally violent deconstructions, and excavations. Decades later, Walter Mignolo was to approach new modalities of knowledge production through the practice of "delinking"; one finds a similar "crack" provoked to counter the universalizing and totalizing work of Eurocentrism when Mignolo calls attention to "the ever-constant struggles, actions, and constructions - the decolonial pedagogies - that fissure or crack the modern/colonial matrix of power" (76). This issue of Commonwealth Essays and Studies is meant as a timely re-assessment of Gordimer's literary experimentations and innovations in their relation to her writerly commitment. Foremost among these concerns we wish to address and qualify the category of realism often used to describe Gordimer's fictional aesthetics, and which in fact tends to morph into fable and the tell-tale, postmodern narrative unreliability and satiric irony. The notion of linearity also extends to the act of reading Gordimer, a writer who tended to favour such fragmented forms as the collection of essays or of short stories. The cumulative nature of such texts is problematic and invites investigations in the direction of epistemological construction through/beyond crisis and fragmentation.

The hallmark scalar distortions in the novels and short stories can thus be seen as a case in point of a technique which both suggests conventional meaning (with the microcosm of the house echoing the macrocosm of the country, the region, or the planet) and curtails conventional meaning (what does "home" (257) mean in "Amnesty," the last short story in Jump?). Meaning is indeed at stake when it comes to the formal examinations of moments of rupture and interruption. It is the meaning of globalization, as disparate as the world itself, in a paradoxical intensification of difference. Appadurai thus writes, "the new global economy has to be seen as a complex, overlapping, disjunctive order that cannot any longer be understood in terms of existing center-periphery models" (32), a statement which resonates with Gordimer's own: "I have used the term 'segment' in defining my place in South African Society" (Essential Gesture 264). This segment seems to be reverberated throughout her works, as a testimony to her own perspectival conundrum. The eight articles in this issue are all concerned with these moments of segmentation, understood in a wide range of ways.

Renowned Gordimer scholar Stephen Clingman opens this volume with an article which is the third in a triptych of recent chapters by him in which he reappraises the

1. Our translation of: “C'est dans cet entre-deux que s'est formé ce livre sur Loudun. Il est lézardé du haut en bas, révélant la combinaison, ou le rapport, qui rend possible l'histoire” (16). 
South African writer's work. In "Gordimer, Interrupted," he retraces the notion of interruption as a signature feature of all of Gordimer's work, from her early and, as Clingman reads it, paradigmatic "Is There Nowhere Else Where We Can Meet?" (1947), through her novels, short stories, and essays, right up to her final novel, No Time Like the Present (2012). Interweaving a biography of Gordimer's writing, close readings, and analyses of punctuation, themes, and narrative form, Clingman deftly shows that interruption is more than just a mere stylistic trait for Gordimer and is, in fact, a complex, fluctuating, and constantly evolving matrix. Interruptions are retraced and explained here, in both re-readings of classics such as The Conservationist (1974) and July's People (1981) and investigations of her more recent fiction, as a means for Gordimer to expose the fault lines of South African society over a period of more than sixty years and as an aesthetics adequate to this task.

Like Clingman, Pascale Tollance focuses on the disruptive power of Gordimer's fiction, although she dwells in particular on the short story form and its relationship to what she calls "the art of the fragment." Tollance analyses the cuts, gaps, voids, and interruptions which permeate Gordimer's short stories and gradually lead, in her later stories, to a dislocation of voice. This article emphasises the many ways in which Gordimer uses her own fiction to "tea[r] at the fictions people live by," and Tollance probes in particular the endings of several stories, thinking through the implications of blunt conclusions in stories such as "Town and Country Lovers" and the omissions (or cuts) in others, such as "Six Feet of the Country" (1956) or "Jump" (1991). The last part of this article homes in on the collection Jump and Other Stories, which Tollance sees as more formally complex, and provides an intricate reading of the manner in which Gordimer toys with continuity and discontinuity as her writing becomes more self-reflexive.

Following the vein of the panoramic yet detailed approach of these first two articles, Liliane Louvel sketches out the contours of Gordimer's sustained and somewhat overlooked engagement with "uncanny elements" throughout her fiction, suggesting that this disrupts the dominant view that her work is predominantly social realist. Zooming in on Gordimer's use of microscopic detail, Louvel delves into the visual dimensions of Gordimer's essays and fiction, frequently establishing links with Virginia Woolf. She also analyses the return of the repressed and its specifically South African implications in stories such as "Something Out There," as well as Gordimer's gestures to Western literary and historical figures who were outsiders on the African continent, such as Joseph Conrad or David Livingstone, in "Livingstone's Companions" (1972) and "Friday's Footprint” (1960). Louvel concludes by extolling Gordimer's talent for exposing simultaneously the rot and the wonder at the heart of South African society.

The intersection of race, gender, and class issues in Gordimer's fiction is explored by Michelle Goins-Reed in her article which reads the post-apartheid novel The Pickup (2001) and a late short story, "The Second Sense" (2007) alongside an earlier collection of short stories, Soldier's Embrace (1980). Notwithstanding Gordimer's own repudiation of the term "feminist writer," and her fraught relationship to feminism generally, GoinsReed analyses these texts from a feminist literary perspective and teases out the ways in which Gordimer engages with gender and race in the domestic and intimate spheres.

Kerry-Jane Wallart moves us away from the domestic and into the public sphere in her examination of the 1991 short story collection Jump and Other Stories from the original angle of cars as voids. Through a series of detailed discussions of individual 
stories, Wallart provides a material analysis of the manner in which Gordimer uses vehicles to stage confrontations, most of which fail. Wallart links Gordimer's interest in the apparently banal presence of vehicles to a long tradition of writing about them in literature from or set on the African continent, evoking the inherently political nature of car ownership in apartheid and post-apartheid South Africa. Supported by Georgio Agamben's work on states of exception, Wallart's article explores the tensions between zoe and bios as related to the liminal spaces of cars which are revealed to be both objective correlatives (or "carrelatives") of the ravages of apartheid and neo-liberalism and spaces of reconfiguration since they are inevitably linked to potential motion. Cars, Wallart shows, are invested by Gordimer with semantic, symbolic, and political dimensions, all of which must be read together.

Audrey Golden, in her article "Nadine Gordimer and the Force of Law: Revisiting My Son's Story," considers the novel published contemporaneously to Jump, which she reads alongside Jacques Derrida's lecture entitled "The Force of Law" and the notion of Bakhtinian literary chronotopes. Noting Gordimer's concern to scrupulously research South African law and transcribe it correctly in her fiction, Golden shows how Gordimer's novel of the transition potentially opens up a space for developing a force of law that operates "outside the ideological constraints of geopolitical time," generating a new literary space-time. Pointing out how Gordimer's interpretation of the "force of law" diverges from Derrida's, Golden goes on to unpack how time and space, within and outside the novel, are intricately linked to the breaking down of ideological boundaries, showing how legal and literary language coalesce in "the intertwined nature of imagination and justice within the Zero chronotope" and in the conception of an ameliorative force of law.

We then return to Gordimer's short stories with Vivek Santayana's article on the late collections Loot (2003) and Beethoven Was One-Sixteenth Black (2007), and the deft interweaving of fable, allegory, and realism in these collections. Like other scholars in this issue, Santayana contests the tendency to view Gordimer's short stories as the poor relation in her oeuvre, dwarfed by her novels, and instead exposes the agenda at stake in using fragmented, non-linear forms in order to respond to the urgencies of postapartheid South Africa. The short story cycle, argues Santayana, is particularly apt at laying bare the combined and uneven development inherent to late capitalism and the post-apartheid era. It also allows for a representation of the different scales of inequality, conflict, and injustice, and thus constitutes "a radical political gesture." Santayana concludes by suggesting that the discussion should be widened to consider the postcolonial short story cycle more generally and "the impact the contexts of production and publication of the short story have on its meaning."

Peter Blair's article on Gordimer's non-fiction and her late-apartheid novels brings this issue to an end, and marks a fitting conclusion to this collective reappraisal of her work. The article's main focus is July's People (1981) which Blair re-reads as a self-reflexive engagement with alterity. Firstly providing a broad yet highly incisive overview of Gordimer criticism, he presents the double-bind of her being considered potentially exploitative in writing about black experience or complicit with apartheid in the case of a failure to engage with it, and relates this to the writer's public pronouncements on this question. This leads him to discuss the central tension between "potential experience" and "the potential of one's own experience," particularly, though not exclusively, in 
relation to July's People. The famously ambivalent ending of this novel is revisited as "a utopian ideal of subjectivity as heuristic, in which experience has the potential to liberate," and Blair makes a strong case for acknowledging that in her fiction "an author's reach might tentatively exceed her grasp."

There can be no doubt that the robust health of critique on Nadine Gordimer, as evidenced by this issue of Commonwealth Essays and Studies, is testimony to the South African author's continued "reach." Taken as a whole, the issue explores Gordimer's inflections and distortions of a context with which she nonetheless never ceased to grapple. As such, it constitutes a useful intervention within the field of South African studies, while also following new lines of flight towards Material Studies, Border Studies, Gender Studies, and Migration/Diaspora Studies. These renewed - and repeatedly displaced - perspectives make way for further understandings of Gordimer's specific de-scribing or dis-scribing of apartheid and its aftermath, at the (aporetic?) crossroads between realism and the fantastic. The tensions between coalescence and disjunction which result from such aesthetic experimentations are, we argue, a new outlining of perceptions, be they sensual or intellectual. These perceptions captured and provoked by Gordimer's writing reconfigure linearity and suggest future regimes of politics and poetics.

Fiona McCANN

University of Lille - IUF

Kerry-Jane WALLART

Sorbonne University - VALE

\section{Works Cited}

Appadurai, Arjun. Modernity at Large: Cultural Dimensions of Globalization. Minneapolis: U of Minnesota P, 1996.

Clingman, Stephen. "Nadine Gordimer: A Writing Life." A Writing Life, Celebrating Nadine Gordimer. Ed. Andries Walter Oliphant. London: Viking, 1998. 3-18.

De Certeau, Michel. La Possession de Loudun. 1970. Paris: Gallimard, 1990.

Gordimer, Nadine. The Late Bourgeois World. London: Gollancz, 1966.

-. "The Short Story in South Africa." "The International Symposium on the Short Story." Special issue, Kenyon Review XXX (1968): 457-63.

—. "Living in the Interregnum." The Essential Gesture: Writing Politics and Places. Ed. Stephen Clingman. London: Cape, 1988. 261-84.

—. Jump and Other Stories. 1990. London: Bloomsbury, 1991.

-.Writing and Being. Cambridge: Harvard UP, 1995.

Mignolo, Walter, and Catherine Walsh. On Decoloniality, Concepts, Analytics, Praxis. Durham: Duke UP, 2018.

Riach, Graham. “The Late Nadine Gordimer." Journal of Southern African Studies 42.6 (November 2016): 1077-94. 